\author{
В.А. Лупандін ${ }^{1}$, Г.В. Мегельбей ${ }^{1}$, В.М. Самойленко ${ }^{2}$, В.Ю. Тюріна ${ }^{1}$ \\ ${ }^{1}$ Харківський національний університет Повітряних Сил ім. І. Кожедуба, Харків \\ ${ }^{2}$ Національна академія Національної гвардї України, Харків
}

\title{
ОБґРУНТУВАННЯ НАПРЯМКІВ ЗАХИСТУ ОБ'ЄКТІВ ТА ОЗБРОЄННЯ I ВІЙСЬКОВОЇ ТЕХНІКИ ВІД РОЇВ БЕЗПІЛОТНИХ ЛІТАЛЬНИХ АПАРАТІВ
}

В статті розглянуті основні підходи щцодо побудови роїв безпілотних літальних апаратів та тактиці застосування роїв безпілотних літальних апаратів. Рій безпілотних літальних апаратів представляє собою групу безпілотних літальних апаратів, щьо об'єднані в рій, котрий керується як одне иіле. Рій може включати у себе однотипні та різнотипні безпілотні літальні апарати, щзо здатні виконувати часткові задачі для досягнення основного завдання рою. У статті проведенні дослідження щьоо ймовірних варіантів побудови роїв безпілотних літальних апаратів та тактики їх застосування. У відповідності до тактики їх застосування визначені найбільш перспективні напрямки протидії роям безпілотних літальних апаратів.

Ключові слова: безпілотний літальний апарат, рій безпілотних літальних апаратів, тактика застосування роїв безпілотних літальних апаратів, ройова зброя, протидія роям безпілотних літальних апаратів.

\section{Вступ}

Постановка проблеми. На сьогоднішній день у світі поширюються розробки зі створення ройової зброї, а саме роїв (груп) безпілотних літальних апаратів (БПЛА). Рій представляє собою групу БПЛА, який керується як одне ціле, може включати у себе однотипні та різнотипні апарати, що здатні виконувати часткові задачі для досягнення основного завдання рою [1].

Аналіз перспектив розвитку та застосування БПЛА свідчить про інтенсивний розвиток в світі технології створення й управління роїв (груп) БПЛА. Рої БПЛА передбачають скоординовані дії апаратів, які взаємодіють між собою та оточуючим середовищем. Кожний апарат виконує прості базові правила, але в сукупності вони діють як складний організм, здатний приймати рішення, формувати маршрути польоту та обирати цілі. Рій не має лідера та може адаптуватися до змін в команді.

Управління здійснює оператор, який стежить за ходом виконання завдання та в будь-який момент часу може втручатись в керування БПЛА.

Планується, що рої БПЛА будуть запускати 3 кораблів, літаків та наземної військової техніки. Вони будуть виконувати завдання з радіоелектронної розвідки, радіоелектронної боротьби та ударні функції.

Також рої БПЛА у своєму складі будуть мати БПЛА різних класів, що значно ускладнює задачу щодо протидії їм.

Протидіяти тактиці ройових систем значно складніше, ніж поодиноким БПЛА, тому проведення досліджень щодо визначення напрямків протидії групам БПЛА є актуальною задачею.

Аналіз останніх досліджень і публікацій. В [1] авторами розглянуті основні тенденції створення та застосування груп безпілотних літальних апаратів в сучасних збройних конфліктах. В [2] розглянуто погляди на перспективи розвитку та застосування БПЛА, а саме, визначено, що перевага у світі надається створенню ройової зброї. Показано, що за концепцією побудови рій спроможний виконувати різні бойові завдання та адаптуватися до різних сценаріїв бойових дій, в тому числі нанесення групового удару.

В [4-10] розглянуті підходи до створення системи управління роями, які на відміну від системи управління поодиноких БПЛА потребують додаткової мережі обміну інформації між БПЛА.

Для створення роїв [6-7] застосовуються БПЛА різних класів, але однією з основних вимог $€$ їх мала вартість. Проте, протидіяти тактиці ройових систем значно складніше ніж поодиноким БПЛА [4-10], що вимагає визначення напрямків захисту об'єктів та озброєння і військової техніки (ОВТ) від роїв БПЛА. Найбільш перспективними способами боротьби 3 роями $\epsilon$ порушення мережі управління з оператором та внутрішніх міжройових зв'язків [5-7].

Мета статті - визначення напрямків захисту та в подальшому розробки концепції захисту об'єктів та озброєння і військової техніки від роїв БПЛА.

\section{Виклад основного матеріалу}

Рій БПЛА має низку переваг проти застосування одиночних апаратів, а саме:

- можливість здійснення координованих атак одночасно з різних напрямків;

- можливість підтримання функцій роя після втрати окремих апаратів;

- можливість ведення розподіленої розвідки або нападу, та навпаки нанесення сфокусованих точкових ударів аналогічних високоточній зброї; 
- застосування роїв для ведення радіоелектронної боротьби в широкому діапазоні частот та інші.

Для ройової зброї можуть використовуватись БПЛА різних класів (нано-, мікро-, міні, тактичних та оперативно-тактичних). Рої можуть виконувати завдання 3 радіоелектронної розвідки, радіоелектронної боротьби (РЕБ) та ударні функції. Відстань між апаратами в рою може бути від десятків сантиметрів до десятків метрів. Рої БПЛА будуть запускати 3 кораблів, літаків та наземної військової техніки.

Незважаючи на те, що загальна тенденція створення ройових систем зброї є зменшення вартості БПЛА, даний вид озброєння $є$ складною системою. Головною проблемою створення подібних роїв $\epsilon$ створення системи обміну інформацією між окремими БПЛА. До складу рою можуть входити БПЛА, які за своїм функціональним призначенням мають різні завдання, а саме: ведення оптико-електронної та (або) радіолокаційної розвідки, виконання ударних завдань відповідно бойового навантаження, мають на борту засоби обробки інформації, зв'язку та передачі даних. На відміну від управління одиночними БПЛА, де є тільки мережа зв'язку “операторБПЛА”, в роях необхідне створення мережі “БПЛАБПЛА”.

Управління роєм може здійснюватися на основі централізованого або децентралізованого підходів [2]. На рис. 1 наведені форми координації роїв та їх міжройових зв'язків.

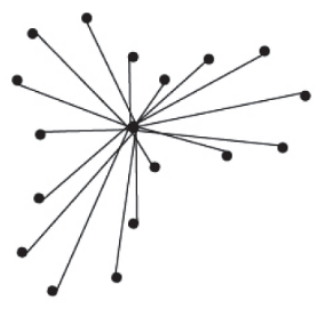

a

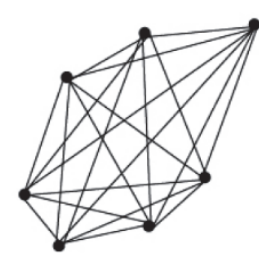

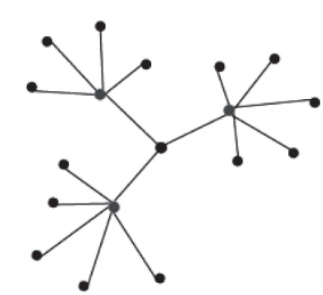

6

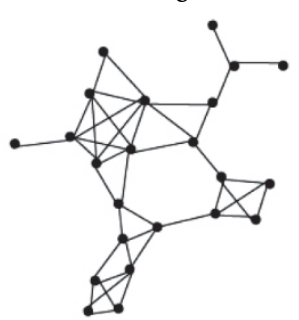

Рис. 1. Моделі управляння та координації роїв: а - централізована; б - ієрархічна; в - консенсусна; $г$ - емерджентна

Джерело: розроблено авторами.

Централізоване управління - елементи роя передають інформацію центральному планувальнику, який ставить задачі кожному елементу окремо.

Ієрархічне управління полягає в тому, що окремі елементи роя контролюються агентами на рівні “підрозділу”, який в свою чергу управляється агентом більш високого рівня, і так далі.

Координація на основі консенсусу, де елементи роя спілкуються один з одним і приймають рішення шляхом голосування або методом аукціону.

Емерджентна координація виникає природнім шляхом між окремими елементами роя, що реагують на інших, подібно зграям тварин.

Кожна з цих моделей має свої переваги та може бути застосована в залежності від ситуації [1-2].

Виходячи 3 огляду перспектив створення роїв БПЛА їх можна поділити за наступними основними ознаками.

Класифікувати рої БПЛА за рівнем застосування та радіусом дії можливо за аналогією одиночних БПЛА, а саме [3]:

- тактичні мікро-БПЛА з радіусом дії до 5 км включно;

- тактичні міні-БПЛА з радіусом з радіусом дії понад 5 км до 25 км включно;

- тактичні малі БПЛА 3 радіусом дії понад 25 км до 50 км включно;

- тактичні й оперативно-тактичні з радіусом дії понад 50 км до 200 км включно;

- оперативні та стратегічні з радіусом дії понад 200 км.

Особливістю роїв БПЛА є те, що деякі зразки мають засоби доставки (літаки, кораблі, наземну техніку), що збільшує їх радіус дії. Але для виключення плутанини в подальшому при класифікації роїв будемо користуватись класифікацією одиночних БПЛА відповідно ДСТУ В 7371:2020 [3].

За призначенням рої БПЛА можуть бути:

- ударні;

- розвідувальні (цілевказання);

- радіоелектронної боротьби;

- багатоцільові.

За способом базування:

- наземного;

- корабельного;

- повітряного.

Виходячи $з$ проведеного аналізу існуючих роїв та перспективних розробок можна визначити, що основними завданнями роїв БПЛА є:

- ведення радіоелектронної розвідки;

- інформаційна підтримка дій наземних підрозділів;

- ураження (дезорганізація) системи протиповітряної оборони (ППО) противника;

- ураження особового складу, позицій артилеpiї, неброньованої та легкоброньованої техніки, морських суден, та інші;

- постановка радіоелектронних перешкод. 
Отже, для виконання зазначених завдань в основному можуть застосовуватись рої БПЛА тактичного класу. В перспективі оперативно-тактичного (типу Стая-93) та стратегічного (типу Gremlins) класу [4]. В табл. 1 наведені дані, щодо створених та перспективних роїв.

Таблиця 1

Характеристики створених та перспективних роїв БПЛА

\begin{tabular}{|c|c|c|c|c|c|c|c|}
\hline $\begin{array}{c}\text { Характеристики } \\
\text { рою } \\
\end{array}$ & Gremlins & LOCUST & Perdix & OFFSET & SWARM & БПАК Стая-93 & Kargu-2 \\
\hline $\begin{array}{c}\text { Країна } \\
\text { виробник }\end{array}$ & США & США & США & США & КНР & РФ & Туреччина \\
\hline $\begin{array}{c}\text { Масштаб } \\
\text { завдань }\end{array}$ & стратегічний & тактичний & поля бою & поля бою & тактичний & $\begin{array}{c}\text { поля бою } \\
\text { (оперативно- } \\
\text { тактичний) }\end{array}$ & - \\
\hline $\begin{array}{c}\text { Кількість БПЛА } \\
\text { в рою } \\
\end{array}$ & $\begin{array}{l}\text { одиниці } \\
(10-20)\end{array}$ & 30 & 103 & до 250 & $10-15$ & $\begin{array}{l}\text { необмежена } \\
\text { (до 100) }\end{array}$ & 29 \\
\hline Радіус дії, км & 900 & 37 & 15 & 15 & 30 & $(140-150)$ & - \\
\hline Призначення & $\begin{array}{l}\text { РЕР, РЕБ, } \\
\text { ударний }\end{array}$ & ударний & ударний & $\begin{array}{c}\text { розвідувальний } \\
\text { інформаційна } \\
\text { підтримка дій } \\
\text { підрозділів }\end{array}$ & $\begin{array}{l}\text { ОЕР, РЛР, } \\
\text { ударний }\end{array}$ & $\begin{array}{c}\text { розвідувальний, } \\
\text { ударний }\end{array}$ & ударний \\
\hline Тип носія & $\begin{array}{c}\text { літак } \\
\text { (B-52, B-1B, } \\
\text { C-130) }\end{array}$ & \begin{tabular}{|} 
корабель, \\
літак, \\
наземна \\
техніка
\end{tabular} & літак & - & - & Зліт з землі & Зліт з землі \\
\hline $\begin{array}{c}\text { Тип пленеру } \\
\text { БПЛА }\end{array}$ & літаковий & літаковий & літаковий & квадрокоптер & $\begin{array}{l}\text { квадрокоптер, } \\
\text { гексокоптер }\end{array}$ & , $\begin{array}{c}\text { квадрокоптер, } \\
\text { моноплан }\end{array}$ & $\begin{array}{c}\text { квадрокоп- } \\
\text { тер } \\
\end{array}$ \\
\hline $\begin{array}{c}\text { Кількість } \\
\text { застосувань }\end{array}$ & багаторазові & камікадзе & камікадзе & багаторазові & багаторазові & $\begin{array}{c}\text { багаторазові, } \\
\text { камікадзе }\end{array}$ & $\begin{array}{c}\text { багаторазо- } \\
\text { ві, каміка- } \\
\text { дзе }\end{array}$ \\
\hline $\begin{array}{c}\text { Швидкість, } \\
\text { км/год. }\end{array}$ & $860-980$ & 157 & 70 & - & - & - & - \\
\hline $\begin{array}{c}\text { Тривалість } \\
\text { польоту } \\
\end{array}$ & до 3-х год. & 1,5 & 0,3 & - & - & - & 0,5 \\
\hline Вага, кг & 350 & 6,4 & 0,3 & - & - & - & 15 \\
\hline $\begin{array}{c}\text { Вага корисного } \\
\text { навантаження, } \\
\text { кг }\end{array}$ & до 70 & 2,3 & - & - & - & 2,5 (до 10) & - \\
\hline $\begin{array}{c}\text { Об'єкти } \\
\text { ураження }\end{array}$ & - & $\begin{array}{c}\text { морські } \\
\text { судна }\end{array}$ & $\begin{array}{c}\text { об’єкти } \\
\text { системи } \\
\text { ППО }\end{array}$ & - & $\begin{array}{l}\text { бронетехніка, } \\
\text { артилерія, } \\
\text { РЛС, вузли } \\
\text { зв’язку, } \\
\text { склади та ін. }\end{array}$ & $\begin{array}{c}\text { одиночні та } \\
\text { групові наземні } \\
\text { та повітряні } \\
\text { цілі системи } \\
\text { ППО }\end{array}$ & $\begin{array}{c}\text { особовий } \\
\text { склад, лег- } \\
\text { коброньо- } \\
\text { вана } \\
\text { техніка }\end{array}$ \\
\hline
\end{tabular}

Джерело: розроблено авторами.

Застосування роїв для ведення радіоелектронної розвідки підвищує надійність та живучість системи розвідки за рахунок властивості динамічного самовідновлення, що надає можливість підтримання функцій роя після втрати окремих апаратів. Ведення розвідки розподіленими роями підвищує достовірність ідентифікації цілей та визначення координат. Достовірність розвідувальної інформації підвищується за рахунок застосування в рої апаратури різних видів розвідки, а саме оптико-електронної, інфрачервоної, радіотехнічної, тощо.

За допомогою розвідувальних роїв БПЛА планується здійснюватися супроводження невеликих підрозділів при веденні бойових дій в густонаселених міських умовах та інших умовах обмеженої видимості [6-7]. Рій БПЛА допомагає сухопутним під- розділам в режимі реального часу отримувати інформацію під час бою про вогневі точки противника, розташування смуги оборони, снайперів, засідки та інші дані. Така інформаційна підтримка дій наземних підрозділів дозволяє підвищити злагодженість, мобільність підрозділів та зменшити втрати особового складу в умовах обмеженої видимості.

Тактика ураження (дезорганізації) системи ППО противника роєм БПЛА схожа 3 нальотом першого ешелону авіаційних засобів масованого авіаційного нальоту [8]. Для виконання цієї задачі планується застосування багатоцільових (комбінованих) роїв, до складу яких мають входити розвідувальні, ударні БПЛА та БПЛА РЕБ.

Застосування роїв БПЛА дозволяє здійснювати координовані атаки одночасно 3 різних напрямків 
або навпаки зосереджувати удари в смузі прориву ППО. Перевагою застосування роїв є те, що різке збільшення кількості повітряних цілей ускладнює обробку радіолокаційної інформації систем та комплексів ППО. Радіолокаційні станції зенітних ракетних комплексів перевантажені великою кількістю цілей, боєкомплекту ракет може не вистачити для ураження всіх БПЛА, що підвищує імовірність прориву вглибину території противника для ураження важливих наземних об’єктів. Крім того, рій БПЛА примушує противника до функціонування багатьох засобів системи ППО, що сприяє викриттю системи ППО та призначенню ударних БПЛА або БПЛА РЕБ на визначені радіолокаційні станції (РЛС) та зенітні ракетні комплекси (ЗРК). Програми управління роями, що розробляються, дозволяють БПЛА діяти синхронно та перебудовуватись для імітації великого авіаційного засобу, наприклад, винищувача або транспортного літака, тим самим вводити противника в оману. Для ураження особового складу, позицій артилерії, неброньованої та легкоброньованої техніки, морських суден та інших цілей концепція роїв може бути адаптована до різних тактичних сценаріїв. У складі роїв застосовуються БПЛА-камікадзе та БПЛА, які оснащені керованими ракетами, бомбами 3 різноманітними видами боєприпасів (осколковими, кумулятивними та ін.), гранатометами та кулеметами. Також до складу роїв входять розвідувальні БПЛА, які оснащені оптико-електронними засобами розвідки, пошуковими РЛС та РЛС наведення [9].

Тактикою застосування передбачається застосування роїв БПЛА для нанесення ударів та ведення розвідки, а також оцінювання результатів вогневого ураження. Крім того, передбачається, що рої можуть застосовуватись для знищення терористичних груп в населених пунктах [6]. Тактика застосування роїв дозволяє здійснювати удари одночасно 3 різних напрямків та навпаки нанесення сфокусованих точкових ударів аналогічних високоточній зброї. Постановка радіоелектронних перешкод з бортів БПЛА дозволяє зменшити потужність передавачів перешкод за рахунок можливості підльоту на невеликі відстані до цілі та можливістю баражування над неї. Застосування роїв для ведення РЕБ надає можливість розподілу між бортами БПЛА передавачів перешкод різних літер в широкому діапазоні частот.

Таким чином, рій БПЛА має низку переваг проти застосування одиночних апаратів, а саме:

- здійснення координованих атак одночасно 3 різних напрямків;

- здійснення узгодженого захисту в обороні, в тому числі проти роїв;

- властивість динамічного самовідновлення надає можливість підтримання функцій роя після втрати окремих апаратів;

- можливість ведення розподіленої розвідки або нападу, та навпаки, нанесення сфокусованих точкових нападів аналогічних високоточній зброї;

- застосування роїв для ведення РЕБ в широкому діапазоні частот;

- шляхом імітації маневруючих повітряних об'єктів вирішувати питання щодо введення противника в оману або створювати хибні цілі;

- ведення розвідки розподіленими роями підвищує достовірність ідентифікації цілей та визначення координат;

- застосування БПЛА-камікадзе.

До основних проблемних питань в розробці та обмежень при застосуванні роїв БПЛА можливо віднести наступні:

- дальність управління роєм обмежується дальністю прямої видимості;

- дальність польоту обмежується джерелами живлення, тому БПЛА невеликих розмірів поки що неможливо застосовувати на великих відстанях;

- побудова рою має виключати зіткнення апаратів між собою та БПЛА не повинні заважати один одному створюваними повітряними потоками;

- БПЛА рою повинні мати можливість колективного перерозподілу апаратів, в залежності від функцій (ударні, розвідувальні, РЕБ) при виході 3 ладу окремих БПЛА;

- необхідність високих обчислювальних можливостей на борту БПЛА для їх взаємодії та обробки розвідувальної інформації в режимі реального часу;

- розробка нового програмного забезпечення для інтеграції системи керування роєм та програмного забезпечення апаратури корисного навантаження БПЛА.

Виходячи 3 проведеного аналізу протидія тактиці роїв значно складніша ніж протидія поодиноким БПЛА. За визначенням іноземних фахівців [10] на сьогоднішній час існуючі засоби ППО не підготовлені до ефективної протидії групам БПЛА. Для знищення БПЛА витрачається велика кількість коштовних боєприпасів. Крім того, існує реальна небезпека розповсюдження тактики застосування БПЛА не тільки державними збройними силами, але й незаконними збройними формуваннями. Терористичні дії із застосуванням БПЛА суттєво підвищують руйнівні наслідки. Тобто, поява реальних загроз, що пов'язана із застосуванням груп БПЛА в терористичних цілях, потребує уваги та прийняття заходів протидії. Відповідно виникає завдання перед ППО держави щодо удосконалення технічних та тактичних спроможностей 3 відбиття окремих БПЛА та роїв. Виходячи з аналізу побудови роїв, покладених завдань, корисного навантаження на борту об'єктами ураження є:

- особовий склад;

- підрозділи на марші та в місцях дислокації;

- автомобільна та легкоброньована техніка; 
- морські судна;

- позиційні райони зенітних ракетних комплексів та РЛС радіотехнічних військ;

- об'єкти державної та військової інфраструктури (арсенали, бази, склади, вузли зв'язку, командні пункти (пункти управління) та ін.).

Під захистом об'єктів та озброєння і військової техніки від роїв БПЛА будемо розуміти комплекс заходів, засобів та органів управління узгоджених за метою, місцем і часом, які спрямовані на ураження БПЛА роїв або зниження ефективності їх застосування. В загальному випадку до складу безпілотних авіаційних комплексів (БПАК) залежно від класифікації та технічних особливостей БПЛА та БПАК, в тому числі й роїв, входять такі компоненти [11]:

- засоби зв'язку з органом управління повітряним рухом та обладнання спостереження (засоби голосового радіозв'язку, зв'язку “керівник польотами - зовнішній пілот (оператор)" по лінії передачі даних, система радіомовного автоматичного залежного спостереження, прийомовідповідач вторинного оглядового радіолокатора, тощо);

- навігаційне обладнання;

- обладнання, що забезпечує зліт та посадку

БПЛА (залежно від способу зльоту та посадки);

- обчислювач управління польотом, система управління польотом та автопілот;

- обладнання контролю технічного стану комплексу;

- система припинення польоту, яка дає змогу в аварійній ситуації контрольованим чином безпечно завершити політ;

- обладнання, що забезпечує повернення БПЛА в район зльоту у разі виходу з ладу лінії керування та контролю;

- озброєння та спеціальне обладнання для виконання бойових і спеціальних завдань (застосування авіаційних засобів ураження, розвідки та цілевказання, радіоелектронної боротьби, спостереження та моніторингу об'єктів, території, тощо). Виходячи 3 цього та аналізу побудови роїв БПЛА можна стверджувати, що основними складовими роїв БПЛА $є$ наступні системи:

- управління;

- виявлення;

- прицілювання;

- ураження.

Засоби захисту військ та об'єктів від роїв БПЛА умовно можна поділити на дві групи:

- засоби ураження БПЛА;

- засоби для зниження ефективності функціонування систем БПЛА.

Для ураження БПЛА застосовується:

- винищувальна авіація (ВА);

- зенітні ракетні комплекси (ЗРК);

- зенітні артилерійські комплекси (ЗАК);

- бойові лазерні системи (БЛС);

- засоби електромагнітної зброї (ЕМЗ) радіодіапазону;

- стрілецька зброя (С3). БПЛА :

Для зниження ефективності застосування

- засоби РЕБ;

- засоби маскування;

- засоби аерозольної протидії;

- фортифікаційне обладнання.

На рис. 2 наведені визначені засоби захисту та ïх можливості щодо впливу на системи БПЛА.

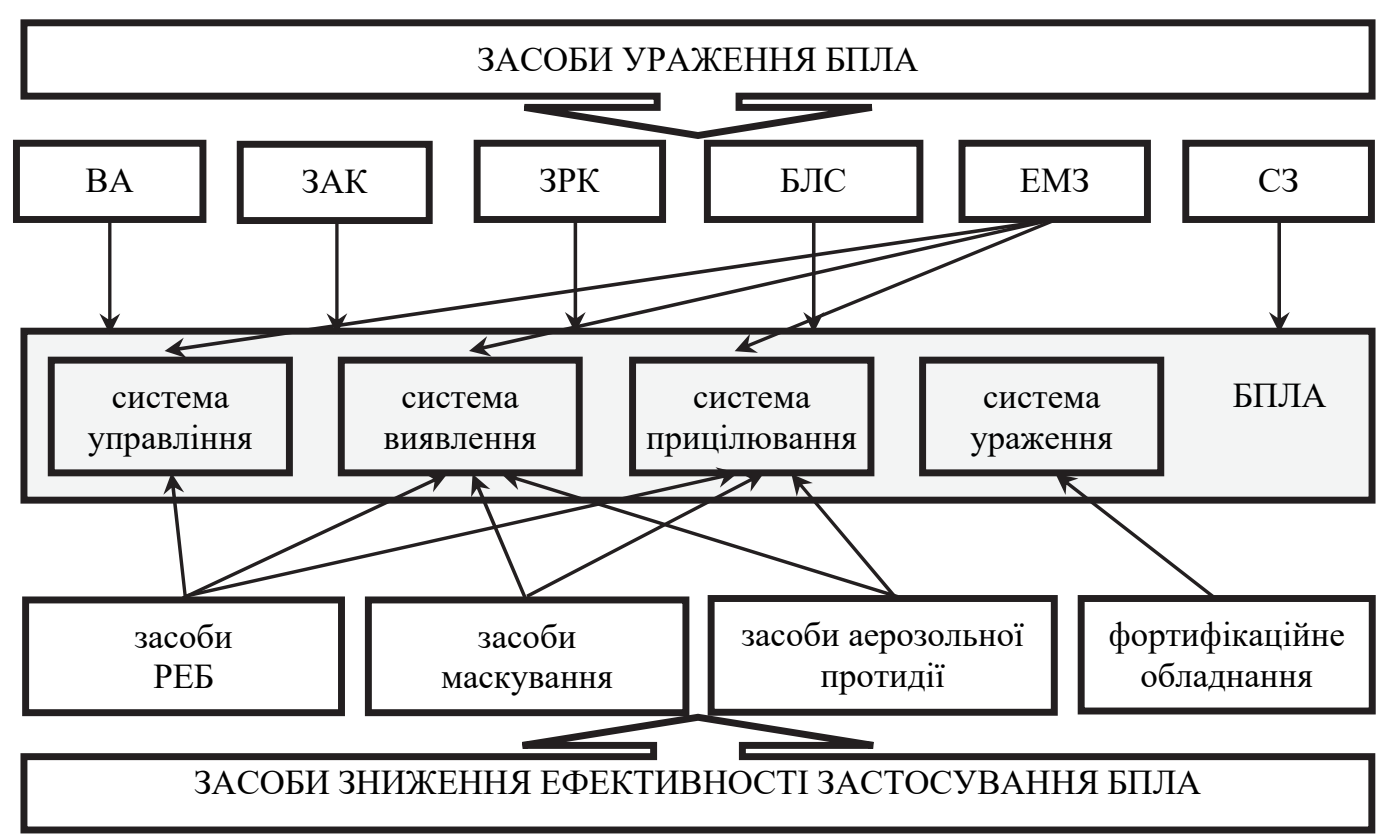

Рис. 2. Засоби захисту та їх можливості щодо впливу на системи БПЛА

Джерело: розроблено авторами. 
Враховуючи те, що рій БПЛА є розподіленою в просторі ціллю зі змінними просторовими розмірами та конфігурацією, вплив на окремі БПЛА точковими ударами $є$ неефективним. Найбільш перспективним засобом ураження роїв БПЛА $є$ електромагнітна зброя радіодіапазону, вражаючим фактором якої є потужне імпульсне електромагнітне випромінювання, під впливом якого радіоелектронні засоби втрачають працездатність. Основною перевагою електромагнітної зброї радіодіапазону є те, що вражаючий електромагнітний імпульс розповсюджується в просторі в межах діаграми спрямованості антени, яка значно більша в порівнянні з лазерною зброєю та засобами вогневого ураження (ЗРК, ЗАК, С3). Засоби РЕБ з БПЛА призначені для порушення управління дистанційно-керованих БПЛА, зниження ефективності їх бойового застосування в ході ведення бойових дій та при запобіганні терористичних актів. Радіоелектронне прикриття об'єктів та ОВТ від БПЛА здійснюється шляхом радіоелектронного подавлення бортових приймачів супутникової навігації, каналів управління й передачі цільової інформації.

Одним 3 перспективних напрямків розвитку засобів РЕБ з БПЛА вважаються перспективні засоби радіоелектронної боротьби, які мають порушувати не тільки мережі управління з оператором та мережі всередині рою БПЛА.

Радіоелектронні системи БПЛА, а саме управління, розвідки, виявлення, наведення, взаємодії між БПЛА та інші використовують радіохвилі. Тому перспективним напрямком захисту об'єктів та ОВТ від роїв БПЛА є модифікація середи розповсюдження радіохвиль 3 метою унеможливлення нормального функціонування радіоелектронних систем БПЛА.
Існуючі засоби модифікації середовища розповсюдження радіохвиль, такі як аерозольні утворення та дипольні відбивачі, мають суттєві недоліки, а саме: вузький діапазон робочих частот та нетривалий час існування завдяки впливу метеорологічних умов. Тому, для захисту об'єктів та ОВТ доцільно створення захисних екранів на основі об'ємних плазмоутворюючих технологій.

\section{Висновки}

БПЛА, що об'єднані в рої, є розподіленою в просторі системою озброєння, яка передбачає скоординовані дії апаратів, які взаємодіють між собою та оточуючим середовищем. Кожний апарат виконує прості базові правила, але у сукупності діють як складний організм, здатний приймати рішення, формувати маршрути польоту та обирати цілі. Рій не має лідера та може адаптуватися до змін в команді.

Управління здійснює оператор, який стежить за ходом виконання завдання та в будь-який момент часу може втручатись в керування БПЛА.

Система управління роями на відміну від системи управління поодиноких БПЛА потребує додаткової мережі обміну інформації між БПЛА. В цій мережі циркулює інформація про позиціонування, орієнтування апаратів у просторі, шикування у бойові порядки відповідно ситуації, що склалася.

На основі аналізу принципів побудови та особливостей функціонування роїв БПЛА визначено, що найбільш перспективними напрямками захисту об'єктів та ОВТ від роїв БПЛА є електромагнітна зброя радіодіапазону, засоби радіоелектронної боротьби та засоби захисту на основі об'ємних плазмових технологій.

\section{Список літератури}

1. Лупандін В. А., Мегельбей Г. В., Мацько О. Й., Куртсеітов Т. Л., Міроненко П. О. Основні тенденції створення та застосування груп безпілотних літальних апаратів та ін. Наука і техніка Повітряних Сил Збройних Сил України. 2019. № 2(35). C. 88-96. https://doi.org/10.30748/nitps.2019.35.11.

2. Савин Л. В. Вариант будущей войны: роение боевых роботов. Стратегическая стабильность. 2017. № 1(78). C. 24-35.

3. ДСТУ В 7371:2020. Техніка авіаційної державної авіації. Апарати літальні безпілотні. Основні терміни та визначення понять. [Чинний від 2021-07-01]. Вид. офіц. Київ, 2021. 16 с. (Інформація та доументація).

4. Бойко А. Рои беспилотников. Robotrends : веб-сайт. URL: http://robotrends.ru/robopedia/roi-bespilotnikov.

5. Агентство DARPA успешно провела тест дронов Gremlins X-61A. Российские беспилотники : веб-сайт. URL: https://russiandrone.ru/news/agentstvo_darpa_uspeshno_provela_test_dronov_gremlins_x_61a/.

6. Зинченко П. Армия США тестирует командное использование дронов и роботов. Comments : веб-сайт. URL: https://comments.ua/news/it/robots/630820-armiya-ssha-testiruet-komandnoe-ispol-zovanie-dronov-i-robotov.html.

7. Юферев С. Рой беспилотников. Будущее боевых действий. Военное обозрение : веб-сайт. URL: https://topwar.ru/164570-roj-bespilotnikov-buduschee-boevyh-dejstvij.html.

8. Створити хаос в системі ППО противника : які можливості буде мати новий російський безпілотний комплекс. Proexpress : веб-сайт. URL: https://proexpress.com.ua/uk/sozdat-haos-v-sisteme-pvo-protivnika-kakimi-vozmojnostiami-bydetobladat-novyi-rossiiskii-bespilotnyi-kompleks.

9. Рой беспилотников. Новая тактика боевых действий уникального оружия Китая. TACC : веб-сайт. URL: http://tass.ru/armiya-i-opk/5786857.

10. "Рой” дронов Пентагона. Cezarium : веб-сайт. URL: http://cezarium.com/swarm-of-drones/.

11. Павлишен О. О., Тимчук Г. М., Цокур Т. В. Посібник для командира підрозділу БпАК. Вінниця : МОУ, 2018.77 с.

12. Шамко В. Є., Жарик О. М., Коваль В. В. Розвиток форм і способів застосування Повітряних Сил Збройних Сил України в сучасних умовах ведення збройної боротьби. Наука і техніка Повітряних Сил Збройних Сил Украӥни. 2018. № 2(31). C. 9-15. https://doi.org/10.30748/nitps.2018.31.01. 


\section{Відомості про авторів:}

Лупандін Володимир Анатолійович кандидат технічних наук старший науковий співробітник начальник науково-дослідного управління

Харківського національного університету

Повітряних Сил ім. І. Кожедуба,

Харків, Україна

https://orcid.org/0000-0001-6060-5894

\section{Мегельбей Ганна Василівна}

кандидат технічних наук старший науковий співробітник провідний науковий співробітник

Харківського національного університету

Повітряних Сил ім. І. Кожедуба,

Харків, Україна

https://orcid.org/0000-0002-2873-4677

Самойленко Валерій Миколайович

ад'юнкт

Національної академії Національної гвардії України,

Харків, Україна

https://orcid.org/0000-0002-0352-3953

\section{Тюріна Валерія Юріївна}

ад'юнкт

Харківського національного університету

Повітряних Сил ім. І. Кожедуба,

Харків, Україна

https://orcid.org/0000-0003-3444-143X

\section{Information about the authors:}

\section{Vladimir Lupandin}

$\mathrm{PhD}$ in Engineering Senior Researcher

Head of Scientific Research Department

of Ivan Kozhedub Kharkiv

National Air Force University,

Kharkiv, Ukraine

https://orcid.org/0000-0001-6060-5894

Hanna Mehelbei

$\mathrm{PhD}$ in Engineering Senior Researcher

Leading Researcher

of Ivan Kozhedub Kharkiv

National Air Force University,

Kharkiv, Ukraine

https://orcid.org/0000-0002-2873-4677

Valeriy Samoylenko

Post-Graduate

of the National Academy of the National Guard of Ukraine,

Kharkiv, Ukraine

https://orcid.org/0000-0002-0352-3953

Valeriia Tiurina

Post-Graduate

of Ivan Kozhedub Kharkiv

National Air Force University,

Kharkiv, Ukraine

https://orcid.org/0000-0003-3444-143X

\title{
ОБОСНОВАНИЕ НАПРАВЛЕНИЙ ЗАЩИТЫ ОБЪЕКТОВ, ВООРУЖЕНИЯ И ВОЕННОЙ ТЕХНИКИ ОТ РОЕВ БЕСПИЛОТНЫХ ЛЕТАТЕЛЬНЫХ АППАРАТОВ
}

\author{
В.А. Лупандин, А.В. Мегельбей, В.Н. Самойленко, В.Ю. Тюрина
}

В статье рассмотрены основные подходы к созданию роев беспилотных летательных аппаратов и тактики применения роев беспилотных летательных аппаратов. Рой беспилотных летательных аппаратов представляет собой группу беспилотных летательных аппаратов, которые объединены в рой, управляемый как единое целое. Рой может состоять из однотипных и разнотипных беспилотных летательных аппаратов, способных самостоятельно выполнять частные задачи для достижения основного задания роя. В статье проведены исследования возможных вариантов построения роев беспилотных летательных аппаратов и тактики их применения. В соответствии с тактикой применения определены более перспективные направления противодействия роям беспилотных летательных аппаратов.

Ключевые слова: беспилотный летательный аппарат, рой беспилотных летальных аппаратов, тендениии развития, роевое оружие, противодействие роям летательных аппаратов.

\section{SUBSTANTIATION OF DIRECTIONS OF PROTECTION OF OBJECTS AND WEAPONS AND MILITARY EQUIPMENT FROM SWORDS OF UNMANNED AIRCRAFT}

\section{Lupandin, H. Mehelbei, V. Samoylenko, V. Tiurina}

The article considers the main approaches to building swarms of unmanned aerial vehicles and tactics of using swarms of unmanned aerial vehicles. An unmanned aerial vehicle swarm is a group of unmanned aerial vehicles that are integrated into a swarm that is controlled as a whole. The swarm may include the same and different types of unmanned aerial vehicles capable of performing partial tasks to achieve the main task of the swarm. The analysis of prospects of development and application of unmanned aerial vehicles testifies to intensive development in the world of technology of creation and management of swarms (groups) of unmanned aerial vehicles. Swarms of unmanned aerial vehicles involve coordinated actions of aircraft that interact with each other and the environment. Each aircraft follows simple basic rules, but together they act as a complex organism capable of making decisions, forming flight routes and choosing targets. Roy has no leader and can adapt to changes in the team. Swarms of unmanned aerial vehicles will include unmanned aerial vehicles of various classes, which greatly complicates the task of countering them. Counteracting the tactics of swarm systems is much more difficult than single unmanned aerial vehicles, so conducting research to determine the direction of counteraction to groups of unmanned aerial vehicles is an urgent task. The article conducts research on probable options for building swarms of unmanned aerial vehicles and tactics of their use. In accordance with the tactics of their use, the most promising areas of counteraction to swarms of unmanned aerial vehicles have been identified. Based on the analysis of the principles of construction and operation of swarms of unmanned aerial vehicles, it is determined that the most promising areas of protection of objects and weapons and military equipment from swarms of unmanned aerial vehicles are electromagnetic weapons, radio warfare and bulk plasma protection.

Keywords: unmanned aerial vehicle, swarm of unmanned aerial vehicles, tactics of application of swarms of unmanned aerial vehicles, swarm weapons, counteraction to swarms of unmanned aerial vehicles. 